УДК 327

DOI dx.doi.org/10.30970/vir.2018.44.0.9445

\title{
SECURITY ENVIRONMENT OF CENTRAL AND EASTERN EUROPE
}

\author{
Marek Żyła \\ War Studies University, \\ al. Gen. Chruściela 103a, Warszawa, Poland, 00-910, tel. +48-22-261813 364, \\ e-mail:m.zyla@akademia.mil.pl
}

Central and Eastern Europe is a region between Western and Eastern Europe and Northern and Southern Europe. These sub-regions are defined in different ways and their delimitation is not consistent. Whatever the approach, the countries that share cultural, historical and political roots should be considered when thinking about CEE. Broadly speaking, it is a part of the continent that was a part of the Soviet bloc. This membership, or rather full political and economic subordination or direct territorial subordination (former Soviet republics), became a common denominator and despite the end of the third decade of independence it still remains one of the most important distinguishing features of the subregion.

Safety environment is usually a derivative of its time. In this respect, particular attention should be paid to security challenges and their perception by relevant international political actors. The dynamic changes that have taken place (NATO and EU expansion, consolidation of NATO's eastern flank countries, increase in the alliance's military presence) cause the knowledge concerning the subregion's security environment to quickly become outdated.

The aim of this article is to present the current conditions of the subregional security environment. Among them, the most important was to define the security dimensions, both in their entirety (regionally) and in detail, referring to the analysis of the most important actors. This serves to get to know and understand their particular interests and national security policies.

Key words: nation; nationalism; common destiny; economic security; military security.

\section{Introduction}

Central and Eastern Europe (CEE) is located between Western and Eastern Europe and Northern and Southern Europe. These subregions are defined differently and the approaches to marking out their outlines are not consistent. Whatever the approach, countries that share cultural, historical and political roots should be considered when thinking about CEEs. In general terms, it is the part of the continent that was a part of the Soviet bloc. This membership, or rather full political and economic subordination or direct territorial subordination (former Soviet republics), became a common denominator and despite the third decade of independence coming to an end, it still remains one of the most important distinguishing features of the subregion.

The safety environment is a derivative of its time. In this respect, particular attention should be paid to the challenges and their perception by the international political actors concerned. Dynamic changes taking place in the subregion make the knowledge about its security environment become obsolete at a rapid pace. Therefore, the aim of the article is to present the current conditions of the subregional security environment. Among them, the most important was to define the security dimensions,

(C) Żyła Marek, 2018 
Marek Żyła

both in their entirety (regionally) and in detail, referring to the analysis of the most important actors. This serves to get to know and understand their particular interests and national security policies.

Today's security environment is characterised by blurring of the boundaries between the internal and external dimensions and between the military and nonmilitary dimensions. Globalisation processes and the pervasive interdependence result in the unpredictability of phenomena occurring in the international environment. They are not constrained by geographical barriers or by political or economic systems. Therefore, the security of the subregion and its individual entities depends on its ability to effectively achieve its strategic objectives in the current and future conditions. This applies to both internal and external challenges, which are the consequence of overlapping political, military, economic and social, demographic, environmental and other processes and phenomena, often not yet defined.

\section{Geopolitical characteristics}

A characteristic feature of the CEE subregion is its transitional location between Germany and Russia. Political and military rivalry between these powers shaped the fate of the area in the 19th and 20th centuries [20, p. 9]. The modern dimension of transition is the location between Western Europe and the Commonwealth of Independent States (CIS). The specific geopolitical location has given the subregion various functions in the past centuries. It was: a bulwark of Christianity, a point of connection between Catholicism and Orthodoxy, a cultural and economic link between western and eastern civilizations, a barrier against the Bolsheviks and a battlefield for both world wars [29, p. 80]. Its western border, including the territory of the former German Democratic Republic (GDR), was the «Iron Curtain» that separated the democratic West from the socialist East.

Central and Eastern Europe, perceived by the powerful ones as a bargaining chip, was torn apart by frequent political changes, bloody wars and ideological indoctrination. This was accompanied by population migration and cultural and ethnic conflicts. Historical conditions, which included periods of annexation, conquest, occupation, repression, national liberation struggle or revolution, contributed to the creation of nationalistic tendencies. The emerging nationalist movements were directed against neighbouring powers (invaders) and, perhaps above all, against neighbours. They were fellow citizens of the same state body, differing in nationality, religion or world view. This created a barrier of mistrust, enmity and hostility, which in extreme cases turned into a tendency to solve all problems by force.

The fate of the subregion was in part connected with various ideas of its unification. These include the approach to this issue by such countries as France, Germany, Poland, Russia (including the USSR), Hungary, Bulgaria, Serbia, Macedonia, Croatia, Romania and Albania. For Germany, CEE was a collection of small and medium-sized countries known as Mitteleuropa or Zentraleuropa, which were an area of possible, often real, domination [31, p. 49-50, 85-87]. The French point of view consisted in the Europe of the turn of the 18th and 19th centuries being united by a force under the rule of the family of Emperor Napoleon I [31, p. 38-40]. Until the third partition of Poland, the Polish approach was the multicultural and, at 
the same time, multi-ethnic Polish-Lithuanian Commonwealth, giving a relative sense of freedom to the noble-born part of society, regardless of their religion or nationality. After 1918, it boiled down to an attempt to establish a federation or a buffer belt in the east, with a special place and role for an independent Ukrainian state, trimmed down in the west [28, p. 17-41]. At the same time, the states of the subregion in the Russian version were based on pan-Slavism, which aimed at «liberating» and unifying the Slavs under the rule of the Tsars [31, p. 50]. After the collapse of the Russian Empire, Soviet Russia sought to transfer the revolution into Europe, seeing it as an opportunity to subjugate it to its own interests. The Yalta-Potsdam geopolitical order enabled the Soviet Union to unite the subregion by imposing its own political and political models. The successor of the Russian and Soviet powers, the Russian Federation (RF), in its expansionist efforts is currently redefining the division of the region into spheres of influence. In the case of Hungary, Bulgaria, Serbia, Macedonia, Croatia, Romania and Albania, simultaneously selected parts of the CEE territory, boiled down to more or less historically justified attempts to create a vast area of nation states [20, p. 365366].

In 1989, breakthrough events took place in the subregion, resulting in the disintegration of the Eastern Bloc. In May 1989 Hungary opened its border with Austria, and in October the opposition agreed with the Communist Party. On 23 August 1989, the citizens of the Soviet Baltic republics, protesting against the enslavement, formed the «Baltic chain», which was seen as the beginning of their aspirations for independence. In November, the Berlin Wall collapsed symbolically, which marked the start of the German reunification process. From 25 to 26 November, about a million protestants took to the streets of Prague. The huge scale of public discontent, later called the Velvet Revolution, led the Czech Communists to relinquish power. Public discontent also resulted in the removal of communists from power in Bulgaria and Romania (December 1989). A derivative of the social protests in the countries of the subregion was the collapse of the Soviet Union, which took place at the end of 1991. It helped may states of the Soviet empire to gain their independence.

\section{Common destinies of nations inhabiting the subregion}

When analysing the analogy of the fate of nations (states) in the CEE subregion, we should start at the end of the 17th century. At that time, two multicultural states functioned within a large part of the subregion - the Polish-Lithuanian Commonwealth and the Habsburg monarchy. In their legacy, some common features of later local statehoods remained. Nations and ethnic groups inhabiting both the Republic of Poland and the Habsburg state were able to use their languages and develop their own culture, to a limited extent. This mixture, both cultural and national, has created a common heritage which, in conjunction with the destinies of individual nations, has influenced the subsequent stages of their history. The Balkans, which were systematically Islamised under the pressure of the Ottoman Turks' Empire until the 19th century, were distinguished by some differences [26, pp. 51-129].

The next historical period, which had an impact on the common fate of the nations, was the 19th century. The subregion, with the exception of the Balkans [173370], was then a part of the absolutist monarchies of Prussia, the Russian Empire and 
Marek Żyła

the aforementioned Austrian Empire. From the point of view of the local nations, this was a period of oppression and denationalisation, with varying degrees of intensity and scale in individual countries, usually combined with political and economic discrimination. In economic terms, the 19th century CEE was, for the most part, a backward and under-industrialised area. Due to its typically agricultural character it was a raw material base and a market for industrial products from outside. In the context of the differences of interest between the states that made up the Holy Alliance, it was seen as the future battlefield in the next war for a new territorial shape and the division of spheres of influence.

The interwar period, with visible similarities in the aspirations of individual nations, was initially characterised by heroic independence rises. In most cases, they transformed into local armed conflicts with a territorial basis. The following years were an attempt to build, or occasionally expand, an industrial and economic base. The aim was to create the conditions for strengthening sovereignty and independence in the new post-Versailles political order. The common feature of countries back then was the course of the borders, which did not coincide with the ethnic range. In many cases, it caused national anxiety.

The end of World War II, or rather the post-war division of influence spheres at the conferences in Yalta and Potsdam (1945), marked the beginning of a new period in the history of the subregion nations. By the decision of the Great Three, all the CEE countries existing until the outbreak of the war were in the Soviet sphere of influence. The exceptions were Lithuania, Latvia and Estonia, which were included in the USSR as socialist Soviet republics. From the first days after the entry of the Red Army, the process of creating communist power began, similar in form and manner of its implementation. It was supervised by a group of «trusted companions», supported by Moscow, who had at their disposal the domestic and Soviet security authorities [56, p. 342-360]. In the newly created socialist countries, industry was nationalised and agricultural reform and collectivisation of agriculture were carried out. After the initial period of moderate and gradual political and social changes, as of 1948 the actions were radicalised. Their aim was to achieve full stalinisation and vassalisation in relation to the Moscow decision-making centre [56, p. 358].

A similar process of forming one's own national identity was another factor which spoke in favour of a «common destinies» of the subregion's nations. The beginning of national consciousness awakening in most of the CEE communities was the period of Napoleonic wars. The modern nation state of the First Empire, functioning as a duplicate model of conduct, became a widely used example of statehood in this part of Europe. This has led indirectly to an increased sense of nationality. The process of its construction gained momentum in the following years. During the Spring of Nations the concept of a «nation» was established in the region in a meaningful way, and the process of building the sense of consciousness and national belonging grew in prominence [56, p. 197].

The oppression and repression exercised by the empires ruling the subregion deepened the sense of harm among the conquered communities at the turn of the $19^{\text {th }}$ and $20^{\text {th }}$ centuries. Particularly burdensome, especially for peasants, were language 
restrictions, degeneration policies and difficulties with religious worship. The privileged strata felt the severe impact of minimising their influence on the way of exercising power. Intelligence, as a layer capable of national self-determination, played a difficult role as an ideologist and organiser of a national movement. Its main task was to awaken the national consciousness among the folk masses, and then to strengthen and merge this consciousness [24, p. 81-89]. At the end of the nineteenth century, political parties and social movements developed, and the sense of national separateness was strengthened in communities that did not have the historical traditions of their own statehood. The emerging movements, in most cases, indicated the recovery or creation of their own statehood as the primary objective of their activities. According to Anthony Smith, the nineteenth-century state-forming ideas, built on the basis of a sense of national identity, put an end to the process of creating a sense of national consciousness in Europe [49, p. 151-152].

\section{Nationalistic tendencies in Central and Eastern Europe}

Nationalism, due to its complexity and typological diversity, does not have a uniform (universal) definition. In terms of range and type, it is divided into western and eastern. In the western perspective, especially in countries with similar territorial ethnic borders, it is a positive factor that unites society [49, p. 58-59]. It integrates the nation into a single, harmoniously cooperating and developing community [24, p. 2]. Eastern European nationalism is a specific variation of this ideology. Its fundamental role is to create one nationality at the expense of the others, who live in the immediate vicinity. It is characteristic of the CEE subregion, where ethnicity has been a decisive factor in many important issues. In this approach, its basic features are fanaticism and referring to the past [58, p. 30-31]. Under the influence of historical conditions, certain resentments have become entrenched among the population inhabiting all contemporary states of the subregion. Nationalism has become their expression. At the same time, it has been a tool for defence against the aggressive aspirations of neighbouring countries and, in many cases, a factor causing mutual distrust and hostility between ethnic groups living on the territory of the same state [20, p. 16].

One of the most important factors influencing the development of nationalistic tendencies is territorial and border controversy [58, p. 73]. They are based on historical, ethnic, economic and political premises. In fact, they concern, with different scales of claims, all the countries of the analysed area. They are partly built on nationalist myths about the concept of «great states». Piotr Eberhardt writes about it mentioning the Great Albania - comprising Kosovo, a large part of Macedonia, the region of Greek Ioannina; the Great Macedonia - comprising Northern Greece (including Thessaloniki) and Bulgarian Piran; the Great Bulgaria - comprising Macedonia and a part of Thrace; the Great Serbia - comprising Bosnia and Herzegovina and large parts of Croatia; the Great Croatia - with Bosnia-Herzegovina and the Serbian region of Silah; the Great Hungary - within the historical borders with Transylvania, Vojvodina, Slovakia and Carpathian Ruthenia; the Great Romania - within the borders of the interwar period with Moldova [20, p. 366]. The author also touches upon the problem of the «Ukrainian» Kubań, Polesie and Chełmszczyzna, the «Polish» Lviv and Vilnius, Belarus «deprived» of Białystok, Vilnius and Smolensk, or 
the «truncated» Lithuania without Sejny, Grodno, Lida and Ashmyany. In addition to the above, it is necessary to mention contemporary disputes and conflicts of a territorial nature, in particular: the Croatian-Serbian dispute over the Croatian Military Frontier and Slavonia, the border problem between Macedonia and Serbia in the area of the Pčinja River, the course of the border between Slovenia and Croatia, the independence of Kosovo, the border dispute between Estonia and Russia, the issue of Moldova and Transnistria, the territorial dispute between Lithuania and Latvia, or the status of Crimea [58, p. 77-81]. Territorial nationalism is complemented by nationalist antagonisms. Taking into account the national and ethnic structure and territorial disputes as potential sources of nationalism, it should be concluded that it is still a serious threat to the subregion's security.

Economic and social conditions are another factor affecting the image of Central and Eastern European nationalism. Once again, the negative effects in this context affected the subregion during the political and economic transformation in the 1990s. The most important economic aspects causing social discontent included: the growing level of internal and external debt, a decline in GDP, liquidation of industrial plants, increased unemployment, a sharp drop in production and market imbalances resulting in higher inflation [58, p. 95-87]. The transformation was accompanied by a significant increase in prices and salaries that did not keep pace with it. This led to a drastic decline in the standard of living [21, p. 20-21]. Impoverished societies, combined with legal and bureaucratic chaos and the failure to adapt the command and control economy to free market conditions, exacerbated dissatisfaction and frustration, and have in many cases became a source of awakening nationalism.

A very important element supporting the processes of creation and formation of nationalisms are psychological factors. Over the centuries they have been inseparably associated with a sense of familiarity and strangeness, acceptance of the individual (group) in society, ethnic myths (mythology) or aversion to strangers and the resulting sense of threat, and concern for the well-being of one's own nation. The most important factors of this type, having a direct or indirect impact on nationalistic attitudes, include: fear, extreme pessimism, feeling of loss and emptiness and the resulting lack of standards and values, the need to belong, the sense of harm (oppression, inequality, backwardness, powerlessness) suffered from another nation, the sense of threat and the resulting lack of security, hostility and passivity [58, p. 104-109]. The final result is the acceptance of nationalism. It usually amounts to perceiving it as a positive factor. The acceptance mechanism is described by Marek Waldenberg by stating that «the motive for the acceptance of nationalism, just like xenophobia in life, is all too often the need to give vent to feelings of insecurity, discharge aggression and find a scapegoat» [55, p. 24-25].

The subregion has been inhabited by a significant number of nationalities and ethnic groups which are in many ways different from each other. This diversity is intensified by the religious divisions that run through the subregion, including between Christianity and Islam, and between Orthodox (Eastern) and Western Christianity. From a cultural point of view, this area has been divided. In common perspective, it is the meeting point of Western and Eastern civilizations. These cultural and religious 
differences have a significant impact on antagonisms, becoming in many cases sources of nationalism.

A historical factor cannot be overlooked when analysing local shades of nationalism. When modern nationalism began to take shape in Europe in the mid-19th century, four monarchies reigned in the CEE subregion of today: Russia. Germany, Austria-Hungary and Turkey [32, p. 54]. In pursuit of their own political goals, they contributed to the outbreak of many wars and conflicts, the direct participants of which were local ethnic groups. These conflicts have resulted in border changes and in population movements, often on a large scale. Moreover, the superpowers consistently implemented the policy of degeneration and arguing against and opposing the enslaved nations $[24$, p. 81-84]. The situation changed partially with the end of the First World War. New state organisms formed in the subregion, the borders of which, under the pressure of the victorious Triple Entente, were attempted to be delimited on the basis of ethnic criteria. This led to the outbreak of further territorially motivated armed conflicts, during which individual states tried to establish their course on their own by means of fait accompli. This has led to radicalisation and further national animosities. A typical example of post-war border demarcation is Hungary, which was territorially cut, and the situation of Ukraine, which, as a result of internal conflict and dispute over the course of future borders, has not managed to maintain its independence. International and national-territorial conditions of the subregion in the interwar period became the basis for the intensively developing nationalist thought. Attempts to artificially solve the territorial and ethnic problem in the years 1918-1921 and after the end of the Second World War did not lead to the elimination of local nationalist attitudes. Each time, they were artificially silenced, often by force, in order to return with doubled power and in the most extreme form in favourable circumstances. This phenomenon is recalled, among others, by David Hooson in his introduction to the global survey «Geography and National Identity»; he wrote: «The second half of the 20th century will go down in history as an era of rampant nationalism, of a nature more lasting than all the terrifyng, albeit bygone, tyrannies that also characterised our century. (...) The strong need to express one's identity and to be genuinely recognised by others is becoming increasingly infectious and must be recognised as a fundamental force even in a shrinking, seemingly homogenised, hightech world at the end of the twentieth century» [11, p. 42].

\section{National and ethnic dimension the subregion's security}

The subregion of Central and Eastern Europe is inhabited by a significant number of nations and ethnic groups [25, p. 81]. Among them, the Slavic nations should be mentioned first, including the most numerous: Ukrainians, Poles, Russians, Belarusians and Czechs. The next are non-Slavic communities, including Romanians, Hungarians, Albanians and Lithuanians. In the past, until the outbreak of World War II, this area had been inhabited by other two large nationalities: Germans and Jews [20, p. 335]. Piotr Eberhardt, analysing the changes in nationality from the end of the First World War to the present day, mentions twenty-one nations inhabiting the subregion [20, p. 350-351]. Some nations have a thousand-year history of separate statehood, while others only have episodic experiences in this area. In a few cases, the 
Marek Żyła

significance of the state in the region was intertwined with the centuries-old tradition of statehood. Such a large number of nationalities and frequently changing administrative and territorial divisions contributed to the emergence of ethnic diasporas, which in turn pose a serious threat in certain circumstances.

State society is made up of one or more groups that are homogeneous in terms of ethnic identity. The groups organised into the society of a multi-ethnic state are often diametrically opposed. They coexist in a specific space, which is the territory of a state, where their national interests usually interfere with each other. This should be taken for granted, because the very fact of otherness creates a real or imaginary threat to others through the feeling of strangeness $[10, \mathrm{p} .66]$. This, in turn, creates a natural need to protect one's own values. The grouping of several communities that are relatively homogeneous and at the same time distinct in their identities is saturated with a wide range of problems, which, within a single territorial organisation, always generates conflicts.

In terms of ethnic security, the subregion's states should be divided into three basic groups. The first is made up of ethnically homogeneous states, where the total number of minorities does not exceed $10 \%$ of the total population. This includes Poland, Croatia, Kosovo, Albania, Hungary and the Czech Republic. Poland is inhabited by 38,501,000 people [59, p. 6]. The rules of the National Census of 2011 allowed for listing two nationalities. The Polish nationality was declared by a total of $36,085,000(93.7 \%)$, including the listing as the only one by 35,767,000 (92.9\%) people, and in the case of 1,862,000 people (4.8\%) no national-ethnic identification was established [59, p. 18]. The largest national and ethnic minorities, counting the first and second listing in total, are: Silesians - 809,000 (2.1\%), Kashubians 228,000 (0.6 \%), Germans - 109,000, (0.3\%), Ukrainians - 48,000 (0.1\%) and Belarusians $-47,000(0.1 \%)$. It follows from the above that minorities who identify themselves nationally with a country other than Poland have a total representation of 204,000 , which is about $0.5 \%$ of the total population living in the country. Croatia is inhabited by 4,285,000 people, including 3,874,000 (90.4 \%) Croats [51]. The significant nations include: Serbs 187,000 (4.4\%), Bosnians 31,000 (0.7 \%), Italians 18,000 (0.4 \%), Albanians 17,000 (0.4\%), Roma 17,000 (0.4\%), Hungarians 14,000 $(0.3 \%)$ and Slovenians 10,000 (0.2\%). These figures show that Croatia is ethnically cohesive. According to the CIA, there were 1,895,200 people living in Kosovo in mid2017 [54]. The main ethnic and national groups, by percentage, were: Albanians $92.9 \%$, Bosnians $-1.6 \%$, Serbs $-1.5 \%$ and Turks $-1.1 \%$. Albania has not been the subject of a comprehensive population census since 1989. According to the CIA, the country was inhabited by 3,048,000 people in mid-2017 [53]. The largest ethnic and national groups were: Albanians $-82.6 \%$, Greeks $-0.9 \%$ and others $-1 \%$. About $15.5 \%$ of the inhabitants did not declare their nationality. The basic language of communication is Albanian, which is used by $98.8 \%$ of the general population of the country. The Czech Republic has 10,436,000 inhabitants [50]. According to the 2011 census, Czech nationality was declared by 6,849,000 (65.6\%), including the listing of Czech nationality only by $6,712,000(64.3 \%)$ persons, and undefined nationality by 2,643,000 (25.3\%). The largest national-ethnic minorities, when considering the 
persons declaring as belonging to one and two nationalities, are: Moravians $-628,000$ (6 \%), Slovaks - 167,000 (1.6\%), Ukrainians - 53,000 (0.5 \%), Poles - 42,000 $(0.4 \%)$, Vietnamese $-30,000(0.3 \%)$, Germans - 25,000 (0.2 \%) and Silesians $21,000(0.2 \%)$. The Czech language is considered to be the native language by $9,263,000(88.8 \%)$ of citizens in the country. The largest national groups, including Vietnamese, who identify themselves nationally with another country, account for a total of 307,000 people $(3 \%)$. In view of the above, it must be concluded that the Czech Republic is ethnically cohesive, recognising the Moravians, the Silesians and the majority of the undeclared as Czech-speaking people. According to the 2011 census, Hungary has 9,938,000 inhabitants, including 8,314,000 (83.7\%) Hungarians and $1,456,000(14.6 \%)$ who refused to answer the nationality question [2, p. 67]. A group of Hungarian citizens, similar in number to the persons declaring no nationality, refused to answer the question of their mother tongue. Analysing the previous censuses, it can be assumed that the majority of them are Hungarian speakers. The significant numbers of national and ethnic minorities include: Roma 309,000 (3.1\%), Germans - 132,000 (1.3\%), Slovaks - 30,000 (0.3\%), Romanians $26,000(0.3 \%)$ and Croats $-23,000(0.2 \%)$ persons.

The second group consists of countries with a dominant and certain position of one nation, where the remaining nationalities oscillate between 10-20\% of the total population. Among the subregion states, these include: Romania, Slovakia, Lithuania, Bulgaria, Slovenia, Serbia and Belarus. The territory of Romania is inhabited by $19,043,000$ people, including 16,879,000 (88.6\%) Romanians [15]. Significantly represented nations include: Hungarians - 1,238,000 (6.5\%), Roma - 619,000 (3.2\%), Ukrainians - 52,000 (0.3\%) and Germans - 37,000 (0.2 \%). Other nations account for $96,000(0.5 \%)$ and 59,000 people $(0.3 \%)$ did not declare their ethnicity. The fact that Romanians do not account for $11.36 \%$ of the total population, however, necessitates Romania to be regarded as an ethnically stable country. According to official data from 2017, Slovakia is inhabited by 5,435,000 people [52]. Its ethnic structure is as follows: Slovaks - 4,421,000 (81.3\%), Hungarians - 455,000 (8.4 \%), Roma - 110,000 (2\%), Czechs and other Czech-speaking ethnic groups - 39,000 $(0.7 \%)$, Ruthenians $-31,000(0.6 \%)$ and Ukrainians $-10,000(0.2 \%)$. Slovaks are a dominant nation, but there are areas in which Hungarians are the predominant or numerically predominant nationalities. According to the 2011 census, Lithuania had $3,043,000$ inhabitants, including 2,561,000 (84.2\%) Lithuanians [1, p. 20]. The largest minorities are: Poles - 200,000 (6.6\%), Russians - 177,000 (5.8\%), Belarusians $36,000(1.2 \%)$ and Ukrainians $-16,000(0.5 \%)$. Lithuanians are the dominant nation. In the Vilnius district Poles make up about $1 / 4$ of the population, and in some of its regions the local majority. Assuming, in a largely simplified way, that Belarusians and Ukrainians potentially use Russian, the problem is the Russian-speaking population. Summing up the population of these nations with Russians, we achieve a result corresponding to $7.5 \%$ of the total population inhabiting the territory of Lithuania. The population of Bulgaria amounts to 6,681,000 people, of which 5,665,000 (84.8\%) are Bulgarians [64]. The largest minorities are Turks - 588,000 (8.8\%) and Roma $325,000(4.9 \%)$. The remaining minorities, in the individual perspective, do not 
Marek Żyła

ISSN 2078-4333. Вісник Львівського університету. Серія міжнародні відносини. 2018. Випуск 44

exceed $0.1 \%$ of the total population. Slovenia has 2,010,000 inhabitants and its ethnic structure is as follows: Slovenes 83.1\%; Serbs $2 \%$; Croats $1.8 \%$; Montenegrins $1.1 \%$; Bosnians $1.1 \%$; Hungarians $0.3 \%$; Albanians 0.3\%; Vlachs (Romanians) $0.1 \%$ and other nationalities $10.1 \%$. In 2011, Serbia had 7,187,000 inhabitants, of whom 5,988,000 (83.3\%) were Serbs and 242,000 (3.4\%) were citizens who did not declare or did not recognise their nationality [63, p. 14]. Among the numerous minorities, the following should be mentioned: Macedonians - 254,000 (3.5\%), Roma - 148,000 (2\%) and Bosnians - 145,000 (2\%). According to the results of the 2009 census, Belarus was inhabited by $9,503,800$ people, including 7,957,200 $(83.7 \%)$ Belarusians [61]. The most numerous national minorities include: Russians $-785,100$ $(8.3 \%)$, Poles $-294,500$ (3.1 \%) and Ukrainians - 158,700 (1.7\%). The declared mother tongue is a serious problem from the point of view of national identity sense. Belarusian as its native language was declared by 5,058,300 (53.2\%) people, and $266,000(2.8 \%)$ did not provide their native language at all. In turn, Russian as the native language was declared by 3,948,100 (41.5\%), including 2,943,800 (31\%) among the respondents declaring Belarusian nationality. According to the census data, Russian is the mother tongue of $41.5 \%$ of the total Belarusian population, including $31 \%$ of ethnic Belarusians. The language situation is much worse when the language of communication (which is used on a daily basis) is used as a determinant of national consciousness [62]. Russian is spoken by 6,673,000 (70.2 \%) people, including $5,551,500(58.4 \%)$ ethnic Belarusians. Belarusian is the language of communication for 2,227,100 (23.4\%) people, including 2,073,800 (21.8\%) ethnic Belarusians. To sum up, Russian is the main language of communication spoken by $70.2 \%$ of the general population of Belarus, and Belarusian by only $23.4 \%$.

The third category is countries in which minorities have a share of more than $20 \%$ in the total population, at least one of which is within the limits of $10 \%$. Moldova, Ukraine, Estonia, Macedonia, Latvia, Bosnia and Herzegovina and Montenegro are definitely multi-ethnic countries. According to the 2004 census, the territory of Moldova is inhabited by 3,383,300 people, including 2,564,800 (75.8 \%) Moldovans [60]. The most numerous national minorities include: Ukrainians - 282,400 (8.4 \%), Russians - 201,200 (5.9\%), Gagauz people - 147,500 (4.4 \%), Romanians - 73,300 $(2.2 \%)$ and Bulgarians - 65,700 (1.9\%) people. A serious problem for Moldova is the language structure of its society, as only 2,029,800 (60 \%) declaring Moldovan nationality also declared Moldavian as their mother tongue and 1,988,500 (58.8\%) declared that they use Moldovan in their daily lives. The Romanian language was declared as native by 558,500 (16.5\%) citizens of the state and Russian by 380,800 $(11.2 \%)$, of which as many as $541,000(16 \%)$ use Russian as their main means of communication. According to the 2001 census, the population of Ukraine comprises $37,541,700$ Ukrainians (77.8 \%), 8,334,100 Russians (17.3\%) and approximately $5 \%$ of representatives of other nationalities [65]. Ukrainian was recognized as the native language by $67 \%$, and Russian by $29.6 \%$ of the citizens of the state. In the eastern and southern oblasts, the members of population declaring Russian as their native language usually account for more than $30 \%$ of the total population. Russian is the mother tongue of $77 \%$ of the Crimea's inhabitants, $75 \%$ of the Donetsk region's 
inhabitants and $69 \%$ of the Luhansk Oblast's inhabitants. In the case of Kiev and Sevastopol, these ratios are $30 \%$ and $90 \%$, respectively. In 2011, Estonia had $1,294,200$ inhabitants and its national structure was as follows: Estonians $-889,800$ (68.7\%), Russians - 321,200 (24.8\%), Ukrainians - 22,300 (1.7\%), Belarusians $12,400(0.9 \%)$, Finns $-7,400(0.6 \%)$ and other nationalities $-3.3 \%$ [42]. Estonian as a native language was declared by 886,800 (68.5 \%), and Russian by 383,100 $(29.6 \%)$ [34]. Estonian citizenship was declared by $1,101,800$ (85.1\%) people, $104,900(8.1 \%)$ had other citizenships and 87,600 (6.8 \%) unspecified or unknown citizenships [41]. Apart from the Russian and Russian-speaking population, a serious problem of this country is the population without any citizenship - a total of $14.9 \%$ of the total population, including $6.8 \%$ of stateless persons. The Republic of Macedonia, internationally referred to as the Former Yugoslav Republic of Macedonia (FYROM), was a country with 2,022,500 inhabitants, according to the 2002 census [13, p. 34]. Its ethnic structure is as follows: Macedonians - 1,298,000 (64.2\%), Albanians - 509,100 (25.2\%), Turks - 77,900 (3.8 \%), Roma - 53,900 $(2.7 \%)$, Serbs - 35,900 (1.8\%), Bosnians - 17,000 (\%), Vlachs - 9,700 (0.8\%) and other nationalities $-21,000(1 \%)$. According to the 2011 census, 2,070,400 people lived in Latvia [44, p. 108]. Its ethnic structure is as follows: Latvians - 1,285,100 (62.1\%), Russians - 557,100 (26.9\%), Belarusians - 68,200 (3.3\%), Ukrainians 45,800 (2.2 \%), Poles - 44,800 (2.2 \%), Lithuanians - 24,500 (1.2 \%), Estonians $2,000(0.1 \%)$ and other nationalities - 42,800 (2.1\%). Taking into account the language of communication, Latvian is spoken by $1,164.900$ (56.3\%) and Russian by $698,700(33.7 \%)$. The fact that 193,500 (9.3\%) Latvians did not declare a particular language of communication is crucial here. Among them, there were 98,900 (4.8\%) Latvians and 63,800 (3.1\%) Russians. Moreover, 335,000 (16.2 \%) of people did not declare Latvian citizenship [44, p. 117]. Out of this number, only 44,300 (2.1\%) are the citizens of other countries, and 290,700 (14\%) should be treated as stateless. According to the 2013 census, Bosnia and Herzegovina was inhabited by 3,531,100 people [14, p. 54]. The main ethnic and national groups are: Bosnians - 1,769,600 (50.1\%), Serbs - 1,086,700 (30.8\%) and Croats - 544,800 (15.4\%). Nationalities other than those mentioned above were reported by $96,500(2.7 \%)$, no nationality was declared by 27,000 $(0.8 \%)$ and 6,500 $(0.2 \%)$ people did not answer this question. According to the 2011 census, the territory of Montenegro was inhabited by 620,000 people [12]. The main national and ethnic minorities are: Montenegrins - 278,900 (45\%), Serbs - 178,100 (28.7\%), Bosnians - 53,600 (8.6\%), Albanians - 30,400 $(4.9 \%)$ and Muslims - 20,500 (3.3\%) people. 30,200 (4.9\%) people did not declare their nationality. The main native languages are: Serbian - 265,900 (42.9\%), Montenegrin - 229,200 (37 \%), Albanian - 32,700 (5.8\%) and Bosnian - 33,100 (5.3\%). The mother tongue was not declared by 24,700 (4\%) people.

\section{Economic security}

The process of economic transformation in the countries of the CEE subregion began with political changes. At the beginning of the 1990s, the previous structures of security and economic cooperation, in which the Soviet Union played a dominant role, collapsed. Most countries of the subregion began efforts to join Euro-Atlantic 
Marek Żyła

ISSN 2078-4333. Вісник Львівського університету. Серія міжнародні відносини. 2018. Випуск 44

economic organisations $[33$, p. 86]. At the same time, sub-regional organisations supporting economic cooperation began to be established. The Visegrad Triangle was established in 1991 (after 1992 - the Visegrad Group, V4), followed by the Central European Free Trade Agreement (CEFTA) in 1992 and the Baltic Free Trade Agreement (BAFTA) in 1993. Some post-Soviet countries (Belarus, Moldova, and Ukraine) established the Commonwealth of Independent States (CIS) in 1991 to support economic cooperation.

The pace and extent of economic reforms in individual countries depended on the political balance of power. Governments dominated by the opposition to date implemented more radical economic and social programmes, as exemplified by Czechoslovakia and Poland, among others. The situation was different in countries where changes in political leadership were only of a cosmetic nature. Such an approach was characteristic of Belarus, Ukraine and Moldova, among others. Conservative economic programmes were implemented there. These countries also adopted the «eastern» direction of economic cooperation, based on cooperation with Russia. Another example in this context are the Baltic republics (Lithuania, Latvia and Estonia), which took a radical approach to privatisation since their independence [4, p. 190]. The post-Slavic area was characterised by an average level of economic transformation. Acceleration in this respect was noted at the end of the last century [5, p. 215]. Initially, the V4 countries were the fastest to implement reforms, and Slovenia and Croatia also stood out. The Baltic States and Macedonia followed. The countries of the CIS area had the weakest reforms. In the second decade of the 21 st century, the leaders of economic change are the leaders of the early 1990s. Eastern European countries have been in relatively low positions. Most of the Balkan countries, especially Montenegro, Serbia, Kosovo and Bosnia and Herzegovina, are equally underdeveloped.

In 1990 the GDP per capita in the subregion countries was relatively low. After the transformational recession, these values fell even lower. The former Soviet republics had the weakest ratings. In 2000, high GDP per capita was characteristic of the V4 countries, as well as Slovenia and Croatia. By 2007, the level of development of the former Soviet republics, Romania and Bulgaria had increased relatively. In 2013, Romania, Belarus, Lithuania and Latvia were among the leaders of the percentage improvement in the economic position. The weakest percentage growth was recorded in the V4 countries, Slovenia and Croatia between 2000 and 2013.

In 2015, the subregion recorded a revival of economic development. Its leaders were: Czech Republic (4.6\%), Romania (3.8\%), Macedonia (3.7\%), Slovakia and Poland (3.6\% each). The biggest decrease took place in the case of Ukraine struggling with internal armed conflict (-9.9). The financial results of large manufacturing companies had a significant impact on the growth trends. Along with the decline of the global GDP growth dynamics in 2016 to the level of 2009, the conditions of economic growth in the EU subregion improved [16]. The economic recovery is supported by external demand for local industrial production. The export sector is the main beneficiary of this recovery. Since the end of 2016, its development has been driving demand on the eastern markets. Consumption appears to remain a key driver 
of the recovery. In some countries, it is further supported by a decreasing tax burden. Taking into account the GDP per capita, the EU countries definitely stand out from the subregion [22]. The situation is slightly different in terms of GDP growth, with postSlavic countries and Moldova present alongside some of today's EU countries. However, it should be stressed that the most dynamic economies are: Poland, the Czech Republic, Romania and Hungary. This is confirmed by EUROSTAT studies based on population size, wages and GDP in market prices [43]. One-way energy dependence on Russia remains a serious problem, especially in the area of natural gas imports [38].

\section{Collective and military security structures}

Assuming the five-stage scale of states power by Zbigniew Lach, it should be recognised that the CEE subregion is generally composed of weak states [30]. Of the twenty cases examined, fourteen were placed in a fifth, lowest category. Only one (Poland) ranks in the first category, two (Ukraine and the Czech Republic) in the third and three (Romania, Hungary and Slovakia) in the fourth category. In total, the powers of all the states in the subregion are comparable to those of Germany and, in some respects, also to those of the Russian Federation. The security of the subregion's states is a derivative of their belonging to certain political, economic and military structures. Apart from organisations covering the entire subregion, an important role is also played by those to which a specific part of the countries belongs. Among these, the EU and NATO should be mentioned first. The Russian point of view, defined in the concept of «near abroad», is also important for the subregional security. It should be understood as an absolute sphere of influence of the Russian Federation that it ascribed to itself.

Another element that has an impact on security is the broadly understood military security complex. In terms of the converted military potential, CEE countries differ significantly from Western European countries. Most of them are located as far as in the third tens [3]. Poland, Ukraine, the Czech Republic and Romania are exceptions to this rule. Military threats from the east are a serious regional problem. The imbalance in military capabilities, excluding nuclear weapons, exacerbates it. It is expressed in the ratio of the CEE countries' military potential to that of Russia. Assuming Russian potential to be $100 \%$, Poland has a potential of $22.1 \%$, Ukraine of $4.8 \%$ and the Baltic States of $0.6 \%$ to $1 \%$. Summing up the selected elements of this capability, which are at the disposal of 9 countries of NATO's eastern flanks, it turns out that they are second in terms of capabilities to two Russian border military districts (Western and Southern). In addition, Russian capabilities are concentrated and centralised in terms of command, and the potential of subregion states should be considered dispersed.

Frequent breaches of airspace and territorial waters by the Russian side are a serious military threat. They usually occur in the Baltic and Black Seas basins. Countries particularly vulnerable to provocation are Lithuania, Latvia and Estonia, which do not have combat aviation [39; 40]. A significant number of airspace infringements were also reported in Bulgaria and Romania [8; 9; 47]. Frequent relocations of units of the Russian Armed Forces and modern combat technology, as 
Marek Żyła

ISSN 2078-4333. Вісник Львівського університету. Серія міжнародні відносини. 2018. Випуск 44

well as the process of forming new tactical relationships, raise serious concerns [27; $37 ; 45 ; 46]$. This is particularly evident in the surroundings of the Baltic States and along the border with Ukraine and at the Crimea. The Russian Armed Forces stationed in the European part are often subject to unannounced tests of their combat readiness, including the ones on a large scale [57, p. 1-9]. According to opinion-forming authorities, the most worrying are the exercises of Russian airborne forces and strike aviation, which in many cases are carried out in border regions [17; 36; 48]. This anxiety verges on the psychosis of permanent threat in countries with low defensive potential [6]. In the opinion of many politicians and military, these exercises are definitely aggressive in nature and course, which indicates an increase in the expeditionary capabilities of the Russian Armed Forces [19, p. 1-2]. The Russian side usually does not hide the fact that they serve to prepare the military component for action in the western direction [35]. One of the aims of such demonstration is to display the quantitative and technical advantage that it has and its ability to start operating in a very short time.

\section{Conclusion}

Central and Eastern Europe is a specific political creation which constitutes a transition area between the Latin Western civilisation and the Ruthenian-Byzantine Eastern civilisation. Historically, these were the former socialist countries to the east of the Iron Curtain, the former Council for Mutual Economic Assistance and the former Warsaw Pact. They are linked by: common destinies; an economic backwardness following the domination of great powers; independence combined with serious economic and political difficulties following the anachronistic economic structures, economic nationalisms and the breakdowns of democracy in the interwar period; the loss of real sovereignty and the Soviet model of political, economic, social and cultural totalitarianism (outside Yugoslavia) in the post-war period; and the growing process of disintegration of the communist system throughout the 1980s. They are characterised by specific differences in the «core countries» of folk democracy (the Catholic Church and the ownership of the means of production in Poland, the reforms of the socialist economic system in Hungary, or the «independence» of Romania's foreign policy), separate ways out of communism (from the Polish-Hungarian model of «regime exchange», through the Czechoslovak model of «regime displacement» to the Balkan model of «system transformation»), and differences in the implementation of the process of political transformation. The perception of the subregion's security has been influenced by many factors, but it seems that the economic and ethnic factors still play the most important role. In terms of nationality policy, the subregion is characterised by a mosaic of different institutional solutions, diversified political practice and various forms of activity taken up by local minorities. In view of the dangers of ethnic diversity, nationality issues are becoming increasingly important.

One of the catalysts for uniting efforts to integrate Central and Eastern Europe is its security. A particularly important element in this respect is its external dimension. At present, it is associated mainly with two elements. These are the refugee crisis and the threats posed by the aggressive policy of the Russian Federation. The first 
concerns the small number of countries in the European Union. Due to the low level of social protection in individual countries, the subregion's territory is not the focus of attention of the migrant masses, but remains only a transit area. The second, due to the blatant disproportion of military potential, is a real threat. It is made credible with the painful experiences of Russian-Soviet domination, which are not very distant in time. During the period of dependency from Soviets, a new potential source of danger for some parts of the CEE region was created, namely Russian and Russian-speaking minorities in post-Soviet states. From the perspective of NATO border states, a real threat is the systematically developed offensive potential of the Russian Federation. Russia has a military presence in Georgia and Ukraine. Its combat capacities in the Baltic and Black Sea basins are increasing. On the territory of the Kaliningrad Oblast and in the Crimea, further tactical formations are being deployed or new ones are being formed. The Baltic Fleet and the Black Sea Fleet are being systematically expanded. During their operations in Syria, Russian troops proved that they were able to successfully conduct operations far from their own territory. Moreover, Moscow is effectively influencing the attitude of selected European countries, especially those in the west of the continent. The intended long-term goal of Russian influence is to weaken relations and solidarity within the alliance and within the EU.

\section{REFERENCES}

1. 2011 m. gyventoju surašymo rezultat, Lietuvos Statistikos Departamentas, https://osp.stat.gov.lt/ documents/10180/217110/Lietuvos_gyventojai_2011.pdf.

2. 2011. Évi népszámlálás. 3. Országos adatok, Központi Statisztikai Hivatal, Budapest 2013, s. 67. http://www.ksh.hu/docs/hun/xftp/idoszaki/nepsz2011/nepsz_orsz_2011.pdf.

3. 2017 Military Strength Ranking The complete Global Firepower list for 2017 puts the military powers of the world into full perspective, https://www.globalfirepower.com/countries-listing.asp.

4. BALCEROWICZ Leszek, Socjalizm, kapitalizm, transformacja. Szkice z przetomu epok, Wydawnictwo Naukowe PWN, Warszawa 1997.

5. BAŁTOWSKI Maciej, KOZARZEWSKI Piotr, Zmiana własnościowa polskiej gospodarki 1989-2013, Polskie Wydawnictwo Ekonomiczne, Warszawa 2014.

6. Baltycka beczka prochu. Analiza militarnego układu sił, http://m.niezalezna.pl/79852-baltyckabeczka-prochu-analiza-militarnego-ukladu-sil, dostęp: 2017.05.29.

7. BOKSZAŃSKI Zbigniew, Stereotypy a kultura, Wydawnictwo Funna, Wrocław 2001.

8. Butgaria skarży się na Rosjan. Wytaczaja transpondery, «tvn24», http://www.tvn24.pl/ wiadomosci-ze-swiata,2/bulgaria-oskarza-rosje-o-powietrzne-prowokacje,663877.html.

9. Butgaria: rosyjskie samoloty tamiq normy międzynarodowe, «Wpwiadomości», http://wiadomosci.wp.pl/bulgaria-rosyjskie-samoloty-lamia-normy-miedzynarodowe6027393716454529a.

10. BYSTROŃ Stanisław, Megalomania narodowa, Wydawnictwo Książka i Wiedza, Warszawa 1995.

11. CASTELLS Manuel, Siła tożsamości, Wydawnictwo Naukowe PWN, Warszawa 2009.

12. Census 2011 data - Montenegro, Statistical Office of Montenegro, http://www.monstat.org/eng/ page.php?id=393\&pageid=57.

13. Census of Population, Households and Dwellings in the Republic of Macedonia, 2002, Republic of Macedonia State Statistical Office, Skopje may 2005, s. 34.

14. Cenzus of population, households and dwellings in Bosnia and Herzegovina, 2013. Final results, Agency for Statistics of Bosnia and Herzegovina, Sarajevo juni 2016.

15. Comunicat de presă 2 februarie 2012 privind rezultatele provizorii ale Recensământului Populației şi Locuințelor - 2011, Comisia Centrală Pentru Recensământul Populației şi al Locuințelor, 
Marek Żyła

http://www.insse.ro/cms/files/statistici/comunicate/alte/2012/Comunicat\%20DATE\%20PROVIZORII\%2 0RPL\%202011.pdf.

16. Cykliczne materiaty analityczne NBP, http://www.nbp.pl/home.aspx?f=/publikacje/nms/ nms.html, [dostęp: 2018.03.09].

17. Ćwiczenia wojsk desantowych Białorusi i Rosji pod Brześciem, «http://wiadomosci.wp.pl/ cwiczenia-wojsk-desantowych-bialorusi-i-rosji-pod-brzesciem-6082108124607617a.

18. DYNER Anna Maria, Rosja wzmacnia potencjał wojskowy na zachodzie państwa, «Biuletyn PISM», 13 czerwca 2016, nr 36.

19. DYNER Anna Maria, Rosyjskie manewry przygotowaniem do działań ekspedycyjnych, «Biuletyn PISM», 25 września 2015, nr 83.

20. EBERHARDT Piotr, Między Rosja a Niemcami, Wydawnictwo Naukowe PWN, Warszawa 1996.

21. Europa Środkowo-Wschodnia 1993. Rocznik III, Instytut Studiów Politycznych PAN, Warszawa 1995.

22. European countries by GDP per capita (2017), https://handbooking.tech.blog/2017/06/16/ european-countries-by-gdp-per-capita-2017/.

23. GRESSEL Gustav, Cicha rewolucja militarna Rosji. Co to znaczy dla Europy?, https://wszystkoconajwazniejsze.pl/gustav-gressel-cicha-rewolucja-militarna-rosji-co-to-znaczy-dlaeuropy/.

24. HELNARSKI Stanisław (red.), Nacjonalizm a problemy bezpieczeństwa Europy Środkowej $i$ Wschodniej, Wydawnictwo AON, Warszawa 1992.

25. HELNARSKI Stanisław (red.), Nacjonalizm, konflikty narodowościowe w Europie Środkowej $i$ Wschodniej, Wydawnictwo Adam Marszałek, Toruń 1994

26. JELAVICH Barbara, Historia Bałkanów wiek XVIII $i$ XIX, Wydawnictwo Uniwersytetu Jagiellońskiego, Kraków 2005.

27. Kaliningrad i Krym czyli ufortyfikowane twierdze Rosji, http://www.fronda.pl/a/kaliningrad-ikrym-czyli-ufortyfikowane-twierdze-rosji,65481.html.

28. KARPUS Zbigniew, REZMER Waldemar, WISZKA Emilian (red.), Polska i Ukraina. Sojusz 1920 roku i jego nastepstwa, Wydawnictwo Uniwersytetu Mikołaja Kopernika, Toruń 1997.

29. KOSIEDOWSKI Wojciech, Regiony Europy Środkowo-Wschodniej w procesie integracji, Uniwersytet Mikołaja Kopernika, Toruń 2008.

30. LACH Zbigniew, Polaka geopolityka $w$ wymiarze subregionalnym, «GEOPOLITYKA.NET», http://geopolityka.net/zbigniew-lach-polska-geopolityka-w-wymiarze-subregionalnym/.

31. ŁASTAWSKI Kazimierz, Od idei do integracji europejskiej, Wydawnictwo Wyższej Szkoły Pedagogicznej Towarzystwa Wiedzy Powszechnej w Warszawie, Warszawa 2003.

32. MOJSIEWICZ Czesław, GLOSS Krzysztof (red.), Przezwyciężanie wrogości i nacjonalizmu w Europie, Wydawnictwo Adam Marszałek, Toruń-Poznań 1993.

33. MOLENDOWSKI Edward, Integracja handlowa w Nowych Państwach Członkowskich (UE10). Doświadczenia $i$ wnioski dla innych krajów Europy Środkowej $i$ Wschodniej, Wydawnictwo Difin, Warszawa 2012.

34. Mother tongue; ability to speak a dialect among the population whose mother tongue is Estonian, 31 December 2011, https://www.stat.ee/sdb-update?db_update_id=13543, [dostęp: 2017.01.05].

35. Na manewrach Zapad 2013 ćwiczono wojne z NATO - Jacek Saryusz-Wolski, członek Rady PISM, dla Polskiego Radia, http://www.pism.pl/PISM-w-mediach/wywiady/Na-manewrach-Zapad-2013cwiczono-wojne-z-NATO-Jacek-Saryusz-Wolski-dla-Polskiego-Radia.

36. Nagłe ćwiczenia rosyjskiego desantu. «Atak na lotniska wroga», https://www.wprost.pl/ 508443/Nagle-cwiczenia-rosyjskiego-desantu-Atak-na-lotniska-wroga.

37. Obwód Kaliningradzki - rakietowy straszak Rosji, http://www.defence24.pl/495863,obwodkaliningradzki-rakietowy-straszak-rosji.

38. Po co Gazpromowi Azja? W Europie zarabia krocie. Najwięcej płaci Polska, https://tvn24bis.pl/wiadomosci-gospodarcze,71/po-co-gazpromowi-azja-w-europie-zarabia-krocienajwiecej-placi-polska,448583.html. 
39. Polskie MiG-i przechwyciły nad Battykiem rosyjski samolot, «onetWIADOMOŚCI», http://wiadomosci.onet.pl/swiat/polskie-mig-i-przechwycily-nad-baltykiem-rosyjski-samolot/y1928.

40. Polskie myśliwce przechwycity rosyjski samolot nad Battykiem, «Defence24», http://www.defence24.pl/news_polskie-mysliwce-przechwycily-rosyjski-samolot-nad-baltykiem.

41. Population by citizenship, 31 December 2011, https://www.stat.ee/sdb-update?db_ update_id=13543.

42. Population by ethnic nationality, 31 December 2011, https://www.stat.ee/sdb-update?db_ update_id=13545.

43. Ranking największych gospodarek w Unii Europejskiej, http://euro-dane.com.pl/wydarzeniagospodarcze-428.

44. Results of the 2011 population and housing census in Latvia, Central Statistical Bureau of Latvia, Ryga 2016.

45. Rosjanie rozmieszczaja nowe dywizje. Również przy granicy $z$ Białorusia, http://wiadomosci.wp.pl/rosjanie-rozmieszczaja-nowe-dywizje-rowniez-przy-granicy-z-bialorusia$6027390734668417 \mathrm{a}$.

46. Rosyjskie Iskandery $w$ obwodzie kaliningradzkim - jest potwierdzenie Moskwy, http://niezalezna.pl/87274-rosyjskie-iskandery-w-obwodzie-kaliningradzkim-jest-potwierdzenie-moskwy.

47. Rosyjskie samoloty częściej naruszaja przestrzeń powietrznq Bułgarii, «onetWIADOMOŚCI», onethttp://wiadomosci.onet.pl/swiat/rosyjskie-samoloty-czesciej-naruszaja-przestrzen-powietrznabulgarii/m309ps.

48. SABAK Juliusz, 2,5 tys. rosyjskich spadochroniarzy ćwiczy przy granicy NATO, http://www.defence24.pl/307954,25-tys-rosyjskich-spadochroniarzy-cwiczy-przy-granicy-nato.

49. SMITH Anthony, Nacjonalizm. Teoria, historia, ideologia, tłum. E. Chomicka, Wydawnictwo Sic!, Warszawa 2007.

50. Spis powszechny 2011. Oficjalne wyniki w ramach Republiki Czeskiej $i$ Województwa Morawsko-Ślaskiego, Koexistencja o.p.s., http://www.coexistentia.cz/spis2011.htm.

51. Stanovništvo prema narodnosti po gradovima/općinama. Popis 2011, https://www.dzs.hr/Hrv/ censuses/census2011/results/htm/H01_01_04/h01_01_04_RH.html.

52. Štatistická ročenka regiónov Slovenska 2017, Vydavatel': Ústredie ŠÚ SR Tématická oblast': Súborné produkty Okruh: Súborné produkty Dátum publikovania: 31.01.2018, Dokument na stiahnutie (zip 14.0 MB), https://slovak.statistics.sk/wps/portal/!ut/p/z1/rZJLc9sgFIV_SxZeIq5ACNQdqTt1O3UTt3EbDKAkE1tPSIRp_n3RWkXfSSZ6UxZwZ3DmXO_e7HCN1g1-uz3Ovi20af43qn8ds0X4vIyl QCcTWGx3E7Xs6sihQzw9e8C8XHzDhaf5afZZplFAcPq9f9fsMLKNqELB7xrzaAPaDhOoLs3J3_U1rsJ nB9NrxuHfq0xVhACJEdMCIcyQg0qnE5RyZktbVUxy-no3Flf4l3FjaUuyxHJLYlq4KjgVKCSas6NM1 Aa92cnf0cdO4EXjhxJqCfJ25mcZ3wFIFYzBgs5326KNaUg6U_BKx5LrPan1vwALxtDxR6r31Wud31y3 8fyIYTuzQQiobYP-pQMIY5qCN4Oycit8ic3TCBok6Rp0pXVc0aHdgj45jkDvIsQ-IsQ3hN8ffbuAW-bt q9jyqt_ZDx_atGbOnmwdQJJSgTPM5JmoiA03se0_uvdnZJxKdomuG8x6H_eiq7e1oIomP1ITDD9vXtdCXlxcV3qwDY2w!!/dz/d5/L2dBISEvZ0FBIS9nQSEh/.

53. The world factbook. Albania, CIA, https://www.cia.gov/library/publications/the-worldfactbook/geos/al.html.

54. The world factbook. Kosovo, CIA, https://www.cia.gov/library/publications/the-worldfactbook/geos/kv.html.

55. WALDENBERG Marek, Kwestie narodowe w Europie Środkowo-Wschodniej, Wydawnictwo Naukowe PWN, Warszawa 1992.

56. WANDYCZ Piotr, Cena wolności, Wydawnictwo Znak, Kraków 2003.

57. WILK Andrzej, Armia rosyjska uzasadnia celowość reform, «Komentarze OSW», 25 czerwca 2013, nr 109.

58. WOJCIECHOWSKI Sebastian, Nacjonalizm w Europie Środkowo-Wschodniej, «Alta 2», Wrocław 2000.

59. Wyniki Narodowego Spisu Powszechnego Ludności i Mieszkań 2011. Podstawowe informacje o sytuacji demograficzno-społecznej ludności Polski oraz zasobach mieszkaniowych, Główny Urząd Statystyczny, Warszawa 2012, https://stat.gov.pl/cps/rde/xbcr/gus/lu_nps2011_wyniki_nsp2011_ 22032012.pdf. 
Marek Żyła

ISSN 2078-4333. Вісник Львівського університету. Серія міжнародні відносини. 2018. Випуск 44

60. Демографические, начиональные, языковые и культурные характеристики, Национальное Бюро Статистики, http://www.statistica.md/pageview.php?l=ru\&idc=295\&id=2234.

61. Население по национальности и родному языку. Республика Беларусь, Перепись населения Республики Беларусь 2009 года, http://www.belstat.gov.by/upload-belstat/upload-belstatpdf/perepis_2009/5.8-0.pdf.

62. Население по национальности и языку, на котором обычно разговаривает дома. Республика Беларусь, Перепись населения Республики Беларусь 2009 года, http://www.belstat. gov.by/upload-belstat/upload-belstat-pdf/perepis_2009/5.9-0.pdf.

63. Национална припадност. Подаци по опитинама и градовима. Попис становништва, домаћинстава и станова 2011. у Републици Србији, Републички завод за статистику, Београд 2012

64. Преброяване на население и жилища фонд в Република България 2011. Население по местоживеене, възраст и етническа група, http://censusresults.nsi.bg/Census/Reports/2/2/R7.aspx\#.

65. Про кількість та склад населення Украӥни за підсумками Всеукраӥнського перепису населення 2001 року, http://2001.ukrcensus.gov.ua/results/general/nationality/.

Стаття надійшла до редколегії 10.06.2018

Прийнята до друку 01.09.2018

\title{
БЕЗПЕКОВЕ СЕРЕДОВИЩЕ ЦЕНТРАЛЬНОЇ ТА СХІДНОЇ ЄВРОПИ
}

\author{
Марек Жила \\ Університет військових наук, \\ Ал. Ген. Грусиеля, 103а, м. Варшава,Польща,00-910, тел. +48-22-261813364, \\ e-mail:m.zyla@akademia.mil.pl
}

Центральна та Східна Свропа - це регіон між Західною та Східною Європою, Північною та Південною Європою. Ці субрегіони визначаються різними способами, i ïx розмежування не узгоджується. Незалежно від підходу, країни, які поділяють культурні, історичні та політичні коріння, повинні враховуватись, коли йдеться про ЦСС. Загалом, це частина континенту, що входила до складу радянського блоку. Це членство, а точніше повне політичне й економічне підпорядкування або безпосереднє територіальне підпорядкування (колишні радянські республіки) стали спільним знаменником i, незважаючи на кінець третього десятиліття незалежності, він залишається одним з найважливіших відмінних рис субрегіону.

Безпекове середовище зазвичай $є$ похідною свого часу. У цьому зв'язку особливу увагу слід приділяти викликам безпеці та їх сприйняттю відповідними міжнародними політичними діячами. Динамічні зміни, що відбулися (розширення НАТО та СС, консолідація країн східного флангу НАТО, збільшення військової присутності Альянсу), призводять до того, що знання щодо безпекового середовища субрегіону втрачає актуальність.

Метою даної статті $є$ представлення сучасних умов субрегіонального безпекового середовища. Серед них найважливішим було визначити чинники безпеки, посилаючись на аналіз найважливіших суб'єктів. Це дає змогу зрозуміти їхні особливі інтереси та політику національної безпеки.

Ключові слова: нація; націоналізм; спільна доля; економічна безпека; військова безпека. 